\title{
W CZTERDZIEŚCI LAT PO PUBLIKACJI WOJEN SPRAWIEDLIWYCH I NIESPRAWIEDLIWYCH MICHAELA WALZERA. KILKA UWAG NA TEMAT ZASADY RÓWNEGO STATUSU MORALNEGO UCZESTNIKÓW DZIAŁAŃ ZBROJNYCH
}

\begin{abstract}
Streszczenie. Artykuł zawiera szkicową analizę jednego z najważniejszych założeń teorii wojny sprawiedliwej zaprezentowanej przez Michaela Walzera w jego głównym dziele poświęconym etyce wojny. Zgodnie z postulatem autora Wojen sprawiedliwych i niesprawiedliwych, kontrowersyjny charakter zasady moralnej równości żołnierzy wyeksponowany zostaje poprzez jej konfrontację z rzeczywistym przebiegiem zdarzeń wyznaczających początek konfliktu zbrojnego, stanowiącego główny przedmiot rozważań Walzera, tj. drugiej wojny światowej. Wykluczenie indywidualnej odpowiedzialności osób biorących udział w operacji militarnej, która nie znajduje żadnego moralnego uzasadnienia, wydaje się pociągać za sobą szereg konsekwencji stanowiących poważne obciążenie dla całościowego modelu Walzera. Utrzymanie niezbędnego poziomu koherencji teorii wojny sprawiedliwej łączy się z koniecznością modyfikacji walzerowskiej zasady równości przynajmniej w odniesieniu do uczestników tzw. wojny wyniszczającej.
\end{abstract}

Słowa kluczowe: etyka wojny, teoria wojny sprawiedliwej, zasada moralnej równości żołnierzy, propaganda wojenna, indywidualna odpowiedzialność moralna

1. Walzerowska zasada moralnej równości żołnierzy i jej krytyka z pozycji rewizjonistycznych.

2. Równościowa teza Walzera a przebieg niemieckiej kampanii wrześniowej 1939 r.

3. Indywidualna odpowiedzialność żołnierzy za uczestnictwo w wojnie wyniszczającej.

Opublikowana w 1977 r. głośna rozprawa Michaela Walzera poświęcona konfliktom zbrojnym ${ }^{1}$ stanowiła nawiązanie do tradycyjnych ujęć etyki wojny, wypracowanych w ciągu minionych kilkunastu wieków na gruncie chrześcijańskiej filozofii moralnej. Podejmując w Wojnach sprawiedliwych i niesprawiedliwych klasyczne

1 M. Walzer, Wojny sprawiedliwe i niesprawiedliwe, tłum. z ang. M. Szczubiałka, Warszawa 2010 
wątki rozważań wokół moralnych aspektów działań militarnych, zaproponował Walzer jednocześnie znaczącą rewizję tych ujęć. Sformułowana w sposób wyrazisty odnowiona wersja teorii wojny sprawiedliwej, doczekała się szeregu krytycznych opracowań, eksponujących kontrowersyjny charakter zarówno kluczowych rozstrzygnięć normatywnych zaproponowanych przez Walzera - takich jak uchylenie standardowych reguł wojny w związku ze „stanem najwyższego zagrożenia” - jak i najbardziej podstawowych założeń leżących u podłoża tejże koncepcji ${ }^{3}$. Jako główny argument w obronie własnego stanowiska prezentuje Walzer tezę o metodologicznej niewspółmierności dominujących współcześnie sposobów uprawiania etyki działań militarnych względem jego własnej perspektywy badawczej, akcentującej pierwszeństwo historycznego - a nie jedynie teoretycznego - kontekstu filozoficznych dociekań nad zjawiskiem wojny ${ }^{4}$. Celem niniejszego artykułu jest podjęcie próby krytycznej analizy jednego z kluczowych elementów teorii Walzera na warunkach proponowanych przez autora Wojen sprawiedliwych i niesprawiedliwych. Przedstawione poniżej uwagi dotyczą Walzerowskiej zasady moralnej równości wszystkich żołnierzy biorących udział w wojnie (tj. „atakujących” i „obrońców”) jako całkowicie niezależnej od kwestii słuszności czy też niesłuszności celów strategicznych, przyświecających poszczególnym stronom zbrojnego konfliktu.

2 Zob. Ch. Toner, Just war and the Supreme Emergency Exemption, The Philosophical Quarterly 55(2005)221, 545-561; D. Statman, Supreme emergencies revisited, Ethics 117(2006)10, 58-79.

3 Zob. J. McMahan, Etyka zabijania na wojnie, w: Etyka wojny, red. T. Kuniński, T. Żuradzki, Warszawa 2009, 101-143.

4 Zob. M. Walzer, Just and Unjust Wars (posłowie do piątego wydania), New York 2015, 335-346. 


\section{WALZEROWSKA ZASADA MORALNEJ RÓWNOŚCI ŻOŁNIERZY I JEJ KRYTYKA Z POZYCJI REWIZJONISTYCZNYCH}

Jednym z najbardziej podstawowych założeń, na których opiera Walzer swoją koncepcję etyki wojny, jest logiczna i aksjologiczna niezależność reguł warunkujących usprawiedliwione wszczynanie wojny (tzw. reguł ad bellum) oraz reguł dotyczących sposobów prowadzenia działań zbrojnych (tzw. regul in bello). Charakterystyczną cechą pierwszego zestawu regul jest to, że odnoszą się one wyłącznie do zbiorowych podmiotów, jakimi są państwa (uznawane przez Walzera, w zgodzie z szerokorozumianą teorią umowy społecznej, za zbiorowości ludzkie wyposażone w uprawnienia, będące pochodną indywidualnych praw tworzących je jednostek, choć zarazem posiadające pewną dozę autonomii, ugruntowaną w fenomenie „wspólnego życia” tychże jednostek ${ }^{5}$ ). To jedynie państwa - poprzez złamanie reguł ad bellum stają się (mogą się stać) agresorami w stosunku do innych państw, podczas gdy poszczególni żołnierze walczący po obydwu stronach frontu zachowują względem siebie moralną równość. „Wojna sama w sobie - pisze Walzer - nie jest relacją między osobami, lecz między

5 Zaistnienie w obrębie danego państwa fenomenu wspólnego życia jego mieszkańców jest, zdaniem Walzera, warunkiem koniecznym do nabycia przez to państwo prawa do zbrojnej obrony własnej suwerenności: „Państwo, w którym nie istnieje wspólne życie albo takie, które nie broni istniejącego wspólnego życia, może nie mieć moralnego usprawiedliwienia dla obrony samego siebie". M. Walzer, Wojny sprawiedliwe i niesprawiedliwe, tłum. z ang. M. Szczubiałka, Warszawa 2010, 105. Uznając realność politycznej wspólnoty będącej czymś więcej niż „sumą” życiowej aktywności wszystkich jej członków, odżegnuje się Walzer zarazem od możliwości przypisania wspólnotowemu życiu jakiejkolwiek formy transcendencji (tamże, 367). Wydaje się jednak - zwłaszcza w kontekście szeroko dyskutowanego stanowiska Walzera dotyczącego szczególnych uprawnień przywódców politycznych w sytuacji tzw. „stanu najwyższego zagrożenia” (supreme emergency) - że teza o swego rodzaju bytowej autonomii państwa pozostaje niezbędnym założeniem teorii politycznej leżącej u podłoża Wojen sprawiedliwych i niesprawiedliwych. Piszę o tym w: A. Cebula, Occasional Inevitability of War Crimes or Ethically Unjustified Hegemony of (Some of) the Rights of Civilians? Some Remarks on the Duplex Nature of Extra-Moral Absolutism, Ethical Perspectives 24(2017)1, 107-122. 
ciałami politycznymi i ich ludzkimi narzędziami. Te ludzkie narzędzia (...) są »takimi samymi biedakami jak ja«, schwytanymi w pułapkę wojny, której nie wywołali. Odkrywam, że są mi równi moralnie". Moralna równość osób toczących (mogących toczyć) ze sobą walkę na polu bitwy staje się elementem przed-politycznych uwarunkowań relacji międzypaństwowych, w ramach których sama wojna jest „(...) stanem moralnym obejmującym podobne przyzwolenie, choć w rzeczywistości nie na poziomie suwerennych państw, lecz armii i indywidualnych żołnierzy. Bez równego prawa do zabijania wojna jako działalność rządzona regułami przestałaby istnieć, a jej miejsce zajęłyby zbrodnia i kara, sprzysiężenia zła i zbrojna egzekucja prawa"7. Walczących na wojnie w imieniu swoich własnych państw żołnierzy nie dotyczy zatem ani w żaden sposób nie obciąża słuszność czy też brak słuszności reprezentowanej przez nich sprawy; jednocześnie wszyscy uczestnicy działań zbrojnych, niezależnie od obiektywnego rozkładu racji między stronami konfliktu, zobowiązani są do przestrzegania reguł określających dozwolone metody prowadzenia walki, tzw. reguł in bello. Naczelne miejsce wśród tych ostatnich zajmuje zasada zabraniająca atakowanie osób niewalczą$\mathrm{cych}^{8}$ - wojna w myśl Walzera, podążającego w tym względzie za większością współczesnych badaczy etyki działań zbrojnych, to prowadzona przez państwa w sposób zorganizowany „walka między walczącymi"

Zaprojektowane w teorii Walzera radykalne odseparowanie reguł ad bellum $\mathrm{i}$ in bello stanowi istotną modyfikację klasycznych postaci

6 M. Walzer, Wojny sprawiedliwe i niesprawiedliwe, dz. cyt., 83.

7 Tamże, s. 89.

8 Przynależność do tej kategorii rozstrzygana jest w oparciu o funkcjonalne powiązania miedzy określonym typem działalności a bezpośrednim przebiegiem działań zbrojnych: „walczącym” będzie np. pracownik zakładów zbrojeniowych czy też kierowca ciężarówki dostarczającej broń na front. Por. E. Anscombe, War and Murder, w: Nuclear Weapons: A Catholic Response, red. W. Stein, London and New York 1961, 45-62.

9 M. Walzer, Wojny sprawiedliwe i niesprawiedliwe, dz. cyt., 91. 
teorii wojny sprawiedliwej, które dopuszczają istnienie związku między moralną oceną indywidualnego zaangażowania w konflikt zbrojny, a możliwością usprawiedliwienia celów przyświecających poszczególnym stronom tegoż konfliktu. Znaczenie słuszności sprawy, o którą prowadzona jest walka, dla uczestniczącej w tej walce jednostki eksponuje w swych pismach Paweł Włodkowic, biorący pod uwagę skomplikowanie relacji wynikających z generalnej zasady podporządkowania indywiduum decyzjom władz politycznych: „tylko poddany ma usprawiedliwienie, gdy pomaga swemu panu, jeżeli zachodzi wątpliwość poparta prawdopodobieństwem, co do sprawiedliwości wojny: ale tu działa węzeł posłuszeństwa, do którego to posłuszeństwa jest obowiązany. I n a c z e j j e st [tj. nie ma usprawiedliwienia - przyp. A.C], gdyby był pewien, że wojna jest niesprawiedliwa, albo z prawdopodobieństwem w to wierzył (...) A nie usprawiedliwia go obawa utraty rzeczy doczesnych, ponieważ choć obawa zmniejsza winę, to jednak zupełnie jej nie wyklucza"10. Mająca swe źródła w pismach św. Augustyna reguła indywidualnej odpowiedzialności za zabijanie osób walczących w słusznej sprawie (odpowiednio ograniczonej stosownie do zasobu wiedzy posiadanej przez szeregowych uczestników wojny niesprawiedliwej, czy też pozostających w ich zasięgu możliwości nabycia/ przetworzenia takiej wiedzy), powtórzona zostaje w sto lat po sporze polsko-krzyżackim, rozstrzygniętym na Soborze Konstancji zgodnie $\mathrm{z}$ argumentacją Włodkowica, przez Francisco de Vitorię ${ }^{11}$.

Nie jest zaskakujące, że podstawowe założenia odnowionej wersji teorii wojny sprawiedliwej autorstwa Walzera stały się przedmiotem ostrego sporu wśród współczesnych myślicieli zajmujących się etyką

10 P. Włodkowic, Saevientibus, w: Dzieła wybrane Pawła Włodkowica, red. L. Ehrlich, vol. I, Warszawa 1968, 65-66, podkreślenie moje.

11 F. de Vitoria, De iure belli, w: Francisco de Vitoria: Political Writings, red. J. Lawrance, A. Pagden, tłum. na ang. J. Lawrance, Cambridge 1991, 306-308. 
wojny. Najbardziej rozpoznawalnym stanowiskiem polemicznym względem poglądów amerykańskiego filozofa jest ich szeroko zakrojona krytyka sformułowana przez Jeffa McMahana. Występując przeciw oddzieleniu reguł ad bellum i in bello prezentuje on tezę, zgodnie z którą status moralny osób walczących w słusznej sprawie jest całkowicie odmienny niż status moralny uczestników działań zbrojnych ukierunkowanych na cel niesłuszny. O ile ci pierwsi zasadniczo "nie czynią niczego, co odbierałoby im prawo do tego, by ich nie atakować czy nie zabijać, nie robią niczego, co pozbawiałoby ich ochrony moralnej przed atakiem", o tyle ci drudzy - w zdecydowanej większości przypadków - „nie mogą uczestniczyć w wojnie nie dopuszczając się zła"12. Głównym powodem takiego stanu rzeczy jest, zdaniem McMahana, brak możliwości spełnienia przez niesłusznie walczących wymogu proporcjonalności (stanowiącego jedną z kluczowych reguf in bello). Tym samym zasada moralnej równości wszystkich żołnierzy biorących udział w wojnie zostaje przez niego w sposób fundamentalny zakwestionowana.

Zasadnicza linia obrony stosowana przez zwolenników Walzerowskiego paradygmatu etyki wojny sprowadza się do podnoszenia względem McMahana i jego „rewizjonistycznych” sprzymierzeńców zarzutu ahistoryczności ich wywodów, mającej w znacznym stopniu dyskredytować prezentowany w nich sposób argumentacji. Przykłady przedstawiane przez przeciwników teorii klasycznej jako dowody jej wadliwości nie są, zdaniem obrońców Walzera, prawidłowo osadzone w kontekście historycznym, cechuje je typowe dla eksperymentów myślowych niedookreślenie, zaś samo

12 J. McMahan, Etyka zabijania na wojnie, w: Etyka wojny, red. T. Kuniński, T. Żuradzki, Warszawa 2009, 114, 122. Wyjątkowymi przypadkami, w których, zdaniem McMahana, następuje odwrócenie ról między walczącymi w słusznej i niesłusznej sprawie w zakresie moralnej oceny ich działania są: i) podjęta przez słusznie walczących próba osiągniecia własnego celu za pomocą niegodziwych środków oraz ii) podjęta przez nich próba realizacji niesprawiedliwego, podrzędnego zamysłu taktycznego w ramach słusznej strategii ogólnej (tamże, 120). 
założenie ich analogiczności do sytuacji rzeczywistych obarczone jest szeregiem epistemologicznych uproszczen ${ }^{13}$. W odniesieniu do centralnej dla swej koncepcji tezy o moralnej równości żołnierzy, przywołuje Walzer - zgodnie z własną metodologią - jej domniemane potwierdzenie $\mathrm{w}$ postaci realnych zdarzeń rozgrywających się w Europie podczas procesów sądowych kończących drugą wojnę światową. Fakt, że przedmiotem takich procesów stało się m.in. zachowanie tysięcy Holendrów kolaborujących z hitlerowskim reżymem, natomiast nie dotyczyły one $\mathrm{w}$ żadnym przypadku działań niemieckich czy włoskich żołnierzy walczących na froncie, potwierdza, zdaniem autora Wojen sprawiedliwych i niesprawiedliwych, zasadność objęcia tej drugiej grupy osób przywilejem moralnej równości przynależnym wszystkim uczestnikom działań zbrojnych, tj. nadania członkom formacji wojskowych zaangażowanych w bezpośrednią agresję przeciw suwerennym państwom statusu równego statusowi ich przeciwników, walczących w obronie własnych krajów: „żołnierze ci (...) robili to, co się wtedy robiło, co robili wszyscy inni; to, co ich rodzice i przyjaciele, nauczyciele i pastorzy, a także przywódcy ich kraju, wskazywali jako działanie słuszne i w ostatecznym rozrachunku nie wymuszaliśmy od żadnego z nich przedstawienia wyjaśnień jego (jej) zachowania. Po raz kolejny zatem dokonaliśmy skolektywizowania ich statusu prawnego i moralnego"14.

\section{RÓWNOŚCIOWA TEZA WALZERA A PRZEBIEG NIEMIECKIEJ KAMPANII WRZEŚNIOWEJ 1939 R.}

Jedną z kluczowych kwestii, które pojawiają się w kontekście zarysowanego wyżej sporu, jest pytanie o możliwość zakwestionowania

13 M. Walzer, Response to McMahan's Paper, Philosophia 34(2006), 43-45; Tenże, Just and Unjust Wars (posłowie do piątego wydania), New York 2015; M. Rigstad, Putting the War Back in Just War Theory. A Critique of Examples, Ethical Perspectives 24(2017)1, 123-144.

14 M. Walzer, Response to McMahan's Paper, tum. z ang. A. Cebula, Philosophia 34(2006), 44. 
nader kontrowersyjnego - jak się wydaje - założenia teorii Walzera przy jednoczesnym zachowaniu pozycji bądź to neutralnej względem obydwu ścierających się ze sobą stanowisk, bądź też życzliwej wobec walzerowskich standardów „realistycznej” metodologii etyki wojny. Innymi słowy, pytanie takie dotyczyć powinno odporności zasady moralnej równości żołnierzy na krytykę uwzględniającą wymóg oparcia wykorzystywanej w niej argumentacji o rzeczywisty - a nie jedynie hipotetyczny - przebieg historycznie udokumentowanych konfliktów zbrojnych. Dla polskiego - czy nawet szerzej: środkowo-europejskiego - obserwatora w głównej mierze anglosaskiej debaty o moralnych aspektach działań militarnych oczywistym wyzwaniem staje się podjęcie naczelnego wątku rozważań amerykańskiego myśliciela, tj. zespołu zagadnień związanych z drugą wojną światową. Czy zatem - ujmując rzecz bezpośrednio, a zarazem z należytym dystansem badawczym - atakujący Polskę we wrześniu 1939 roku niemieccy żołnierze zachowywali w istocie identyczny status moralny, co stawiający im opór członkowie polskich formacji wojskowych?

Potraktowanie - zgodnie z rozumowaniem Walzera - kryterium prawnej odpowiedzialności uczestników działań zbrojnych, stosowanego w powojennych procesach karnych, jako dowodu na moralne zrównanie żołnierzy-napastników i żołnierzy-obrońców nie wydaje się przekonujące. Na czysto pragmatyczne powody stosowania takiego kryterium, odpowiadającego obowiązującym w tym względzie ogólnym konwencjom międzynarodowym, zwraca uwage $\mathrm{w}$ polemice $\mathrm{z}$ autorem Wojen sprawiedliwych $i$ niesprawiedliwych Jeff McMahan ${ }^{15}$. Niezależnie od ewidentnego w takim przypadku braku

15 Powodami tymi są, zdaniem McMahana, brak możliwości przeprowadzenia uczciwych procesów sądowych tak wielkiej liczby osób przez jakikolwiek kraj czy nawet podmiot międzynarodowy, nieuchronna skłonność zwycięzców wojny, by dokonywać odwetu na żołnierzach przegranej armii, a także niebezpieczeństwo przedłużania się konfliktów wojennych w sytuacji obawy żołnierzy przegrywającej armii o swój los (odstraszenia ich od poddawania się w ręce zwycięzców). J. McMahan, Etyka zabijania na wojnie, dz. cyt., 139. J. McMahan, Killing in War: A Reply to Walzer, Philosophia 34(2006), 50. 
mocy rozstrzygającej argumentu Walzera, poważne wątpliwości budzi już samo uznanie standardowych procedur prawno-karnych za formułę (ostatecznego?) moralnego rozliczenia zbrodni popełnionych podczas II wojny światowej. Podstawowym testem dla walzerowskiej tezy o moralnej równości wszystkich uczestników walk frontowych w latach 1939-1945 jest zatem rozpatrzenie jej w kontekście rzeczywistych zdarzeń składających się - w pierwszym rzędzie - na zwycięską kampanię wojsk hitlerowskich wczesną jesienią $1939 \mathrm{r}$. Atak na Polskę 1 września 1939 r. był zasadniczo pierwszym aktem bojowego wykorzystania sił wojskowych Trzeciej Rzeszy - we wcześniejszym okresie niemiecki Wehrmacht „zdążył się przyzwyczaić do zajmowania bez wysiłku krajów, które już wcześniej się poddały, jak Austria czy Czechosłowacja”16. Nawet jeśli zgodzić się z obrońcami teorii klasycznej, że przedstawiana przez McMahana interpretacja zbrojnej napaści na suwerenne państwo jako (przynajmniej) jednej takiej fazy wojny niesprawiedliwej, „w której niesłusznie walczący [atakując niewalczących żołnierzy atakowanego państwa] nie mogą uczestniczyć nie dopuszczając się zła" ${ }^{\prime 17}$, jest obarczona typową dla teorii rewizjonistycznej idealizacją realiów wojennego konfliktu, początek działań armii niemieckiej na terenie Polski podważa i tak w sposób znaczący możliwość utrzymania względem nich kluczowej

16 T. Snyder, Skrwawione ziemie. Europa między Hitlerem a Stalinem, tłum. z ang. B. Pietrzyk, Warszawa 2015, 142.

17 „[W]alczących uważa się za uprawnione cele z tej racji, iż zagrażając innym, tracą prawo do tego, by ich nie atakować. Otóż członkowie stałej armii stacjonującej na własnym terytorium, służącej wyłącznie celom obronnym, niezmobilizowanej i nieposiadającej planów wojennych nie zagrażają innym - są niewinni w istotnym tu sensie. Twierdząc, że są walczącymi, naruszamy związek między statusem walczących a przyjętym w teorii tradycyjnej kryterium, kogo wolno atakować. (...) [Niezmobilizowani wojskowi] podlegają (...) ochronie przed umyślnym atakiem, ci zaś, którzy wszczynają wojnę niesprawiedliwą, atakując ich, dopuszczają się naruszenia zawartego w ius in bello wymogu rozróżniania. Jeżeli tak jest, to wojna niesprawiedliwa ma przynajmniej jedną taką fazę, w której niesłusznie walczący nie mogą uczestniczyć bez dopuszczania się zła”. J. McMahan, Etyka zabijania na wojnie, dz. cyt., 104-105. 
dla teorii Walzera cezury między ius ad bellum a ius in bello. Wbrew utrwalonej w historiografii światowej opinii na temat momentu rozpoczęcia II wojny światowej, chronologicznie pierwszym celem niemieckiej operacji militarnej nie była polska baza wojskowa na Westerplatte, ale pozbawiony jakiegokolwiek militarnego znaczenia kilkunastotysięczny Wieluń. W wyniku nalotów Luftwaffe, rozpoczętych 1 września o 4.40, śmierć poniosło ok. 1200 mieszkańców miasta, setki kolejnych odniosło rany, zaś 70\% miejskiej zabudowy uległo całkowitemu zniszczeniu ${ }^{18}$.

Zainicjowania działań wojennych atakiem na bezbronnych cywilów, a więc złamaniem najbardziej podstawowej zasady ius in bello,

18 Najnowsze pozycje anglosaskiej literatury historycznej poświęcone II wojnie światowej, takie jak Skrwawione ziemie T. Snydera, uwzględniają już bombardowanie Wielunia jako pierwszy akt działań zbrojnych niemieckiego Wehrmachtu w 1939 r.: „Niemiecki terror rozpoczął się w powietrzu. Dwadzieścia minut po czwartej rano 1 września 1939 roku bomby spadły bez ostrzeżenia na położony w środkowej Polsce Wieluń. Za cel zabójczego eksperymentu Niemcy wybrali miejscowość bez żadnego znaczenia wojskowego. Pytanie brzmiało: czy nowoczesne lotnictwo może sterroryzować ludność cywilną dokonanym z premedytacją nalotem? Kościół, synagoga i szpital stanęły w płomieniach. Bomby w sumie siedemdziesiąt ton - spadały kolejnymi falami, niszcząc większość budynków i zabijając setki osób, głównie kobiety oraz dzieci. Mieszkańcy uciekli z miasta; niemiecki zarządca zastał po przybyciu więcej zwłok niż żywych ludzi. Dziesiątki miasteczek i wsi zachodniej Polski spotkał podobny los. Zbombardowano 158 miejscowości". T. Snyder, Skrwawione ziemie. Europa między Hitlerem a Stalinem, dz. cyt., 141. Niezwykle znacząca w kontekście stopniowego odkrywania przez zachodnią historiografię rzeczywistego charakteru niemieckiej agresji na Polskę w 1939 r. jest opinia Normana Daviesa: "On 1 September 1939, the Luftwaffe targeted Wielun for its very first bombing raid. The bombs started falling by some accounts at $4.30 \mathrm{am}$ and by others at $4.40 \mathrm{am}$; at all events several clear minutes before the opening salvo at Westerplatte. About 1,290 townspeople were killed in their beds. Three-quarters of the town was pulverised. The casualty rate was more than twice as high as Guernica or Coventry. But hardly anyone outside Wielun recalls it. The 50,000 people killed by German bombs in Warsaw in September 1939, and the 200,000 killed in similar circumstances during the Warsaw uprising of 1944, serve as Poland's major memories of bombing. For whatever reason, Wielun - to use the technical phrase - is not a lieu de mémoire." N. Davies, We must not forget the real causes of the war, The Independent 28.08.2009, http://www.independent.co.uk/voices/commentators/ we-must-not-forget-the-real-causes-of-the-war-1778973.html (dostęp: 16 maja 2017). 
nie daje się opisać za pomocą konstrukcji pojęciowej leżącej u podłoża walzerowskiej etyki wojny. Dokonane w ramach systematycznie zaplanowanej operacji wojskowej przez elitarną jednostkę wyjątkowo zdyscyplinowanej armii, nie może ono zostać „wyłączone” z ciągu zdarzeń składających się na akt instytucjonalnej agresji jednego suwerennego państwa przeciw drugiemu. Owa państwowa agresja, obejmująca jako swój integralny element składowy zabijanie osób niewalczących, jawić się jednak musi z punktu widzenia teorii Walzera jako zjawisko hybrydowe. Zgodnie z tą koncepcją, zakładającą - warto przypomnieć - wyraźny rozdział między ius ad bellum i ius in bello, agresja (złamanie regul ius ad bellum) to ,jedyna zbrodnia, jaką państwo może popełnić na innych państwach"19. I choć wśród podmiotów zobowiązanych do przestrzegania reguł określających dopuszczalne sposoby prowadzenia działań zbrojnych wymienia Walzer zarówno państwa, jak i poszczególnych żołnierzy biorących udział w wojnie ${ }^{20}$, to zasadnicza logika jego wywodów dotyczących ius in bello opiera się na idei odpowiedzialności indywidualnej: za zbrodnie stanowiące pogwałcenie tych reguł odpowiadają bezpośrednio żołnierze i ich dowódcy. W przypadku niemieckiej napaści na Polskę w 1939 r. wymóg indywidualnego rozliczenia sprawców zbrodni wojennych (w znacznej mierze $-\mathrm{z}$ wielu powodów, w tym również wspomnianych wyżej powodów „pragmatycznych” - niewypełniony) nie budzi oczywiście na gruncie teorii Walzera żadnych wątpliwości. Sprawą kluczową przy analizie pierwszej operacji militarnej nazistowskich Niemiec (a także znakomitej większości niemieckich działań zbrojnych w czasie II wojny światowej) jest natomiast odpowiedź na pytanie, czy samo uczestnictwo w tym przedsięwzięciu - zarówno osób dokonujących określonych zbrodni wojennych na jego poszczególnych etapach, jak i osób, które nie były

19 M. Walzer, Wojny sprawiedliwe i niesprawiedliwe, dz. cyt., 101.

20 Tamże, 201. 
w te zbrodnie bezpośrednio zaangażowane - nie było od początku działaniem moralnie nagannym.

Skoordynowana akcja państwa-agresora, ukierunkowana w równym stopniu na zabijanie walczących w obronie własnego kraju żołnierzy, jak i na mordowanie bezbronnych cywilów, to z pewnością coś zupełnie innego niż klasyczny atak zbrojny, rozpatrywany przez autora Wojen sprawiedliwych i niesprawiedliwych jako standardowe naruszenie reguł ius ad bellum (w ramach którego dochodzić może do bardziej lub mniej odosobnionych przypadków łamania ius in bello). O konieczności znalezienia dla niemieckiej kampanii z września 1939 r. całkowicie odmiennej formuły pojęciowej przesądzać musi fakt, że bombardowanie domostw śpiących mieszkańców Wielunia nie było w żadnym wypadku "punktem osobliwości” trwającej pięć tygodni operacji wojsk Wehrmachtu na terenie Polski. Odkrywany w ostatnich latach przez zachodnią historiografię rzeczywisty przebieg tej operacji nie pozostawia wątpliwości, że systematyczne naruszanie najbardziej podstawowych konwencji wojennych stanowiło jedną z charakterystycznych metod działania sił zbrojnych Trzeciej Rzeszy $^{21}$. Zgodnie z ustaleniami historyków, w trakcie jesiennych walk 1939 r. los Wielunia podzieliły w mniejszym lub większym stopniu setki polskich miast i miasteczek, lotnictwo niemieckie masakrowało całe kolumny uciekających z miast cywilów, niemieckie

21 O dynamice i wieloetapowym przebiegu dyskusji toczonej na temat zbrodniczego charakteru działań Wehrmachtu w obszarze historiografii niemieckiej pisze niemiecki historyk Jochen Böhler (J. Böhler, Wojna z Polską w 1939 r. w historiografii zachodnioniemieckiej, w: Spojrzenie na Polski Wrzesień 1939, red. T. Kondracki, Warszawa 2011). Jest on autorem kilku głośnych opracowań dotyczących zbrodni dokonywanych na terenie Polski przez niemiecką armię (J. Böhler, Zbrodnie Wehrmachtu w Polsce. Wrzesień 1939. Wojna totalna, Kraków 2009; Tenże, Najazd 1939. Niemcy przeciw Polsce, tłum. z niem. D. Salomon, Kraków 2011). W literaturze polskiej znaczącą pozycję zajmuje wciąż przełomowa praca poświęcona tej tematyce autorstwa Szymona Dantera (Sz. Danter, 55 dni Wehrmachtu w Polsce. Zbrodnie na polskiej ludności cywilnej w okresie 1.XI-25. X. 1939, Warszawa 1967.) Na ustalenia obydwu autorów powołuje się w cytowanym w niniejszym artykule dziele T. Snyder. 
oddziały wojskowe dokonywały tysięcy egzekucji na ludności cywilnej - zarówno przy zdobywaniu, jak i czasowej utracie poszczególnych fragmentów pola wali, rozstrzeliwani byli masowo wzięci do niewoli polscy żołnierze (zginęło ich w ten sposób nie mniej niż trzy tysiące), w zdobytych miastach grupy niemieckich żołnierzy dopuszczały się gwałtów i rozbojów (zwłaszcza na ludności żydowskiej)22. Zarówno skala, jak i częstotliwość tych działań wskazują w sposób dobitny, że stanowiły one integralną część wojennej strategii, realizowanej przez niemieckie wojska z pełną konsekwencją. Uznanie

22 T. Snyder Skrwawione ziemie. Europa między Hitlerem a Stalinem, dz. cyt., 141-145. Szymon Danter wymienia następujące zbrodnicze metody działań wojennych stosowane bezpośrednio przez wojska Wehrmachtu, bądź też przez inne niemieckie formacje policyjne i paramilitarne, za których działania na terenie Polski w okresie od 1.09.1939 do 25.10 .1939 r. (tj. do momentu przekazania władzom cywilnym administracji nad okupowanym terytorium) niemieckie siły zbrojne ponosiły pełną odpowiedzialność:

„- agresja zbrojna (najazd) bez obowiązującego prawem międzynarodowym wypowiedzenia wojny,

- bombardowanie otwartych miast przez artylerię lub lotnictwo,

- inne terrorystyczne metody wojny lotniczej,

- zbrodnicze metody prowadzenia wojny na morzu, jak zatapianie statków państw neutralnych i statków pasażerskich bez ostrzeżenia, rozstrzeliwanie na pełnym morzu dryfujących lub pływających członków załóg zatopionych okrętów wojennych oraz statków handlowych lub pasażerskich,

- mordowanie jeńców wojennych na placu boju, w punktach zbiorczych, w czasie transportu i w obozach stałych;

- mordowanie ludności cywilnej w zdobytych miastach i osiedlach, branie zakładników spośród ludności cywilnej i mordowanie ich za nie popełnione przez nich czyny,

- zmuszanie jeńców wojennych i ludności cywilnej do udziału w działaniach wojennych przez tworzenie z nich „żywych osłon” przed atakującymi własnymi wojskami, tworzenie takich „osłon” przed atakowanymi własnymi wojskami i osadzanie zakładników w obiektach ważnych ze względów wojskowych dla osłony przed atakiem nieprzyjaciela, - palenie wsi, osiedli i miast oraz niszczenie dobytku oraz własności publicznej i prywatnej bez wojskowej konieczności, dla siania terroru; grabież zorganizowana i indywidualna własności publicznej i prywatnej,

- zmuszanie jeńców wojennych i ludności cywilnej okupowanego kraju do wykonywania prac zabronionych przez prawo międzynarodowe - skierowanych przeciwko ich ojczyźnie itd." (Sz. Danter, 55 dni Wehrmachtu w Polsce. Zbrodnie na polskiej ludności cywilnej w okresie 1.XI-25. X. 1939, Warszawa 1967, 48)". 
wraz z Walzerem, że uczestnicy tej operacji - nawet ci (być może stanowiący większość walczących po stronie nazistowskich Niemiec), którzy ustrzegli się bezpośredniego zaangażowania w dokonywane systematycznie zbrodnie wojenne - mogli zachować status moralny równy statusowi obrońców mordowanych cywilów, nie wydaje się $\mathrm{w}$ tej sytuacji możliwe. Jest rzeczą oczywistą, iż stopień indywidualnej odpowiedzialności żołnierzy Trzeciej Rzeszy kształtować się musiał odmiennie w zależności od specyfiki poszczególnych przypadków: możliwość znalezienia stosownego „wytłumaczenia” własnego udziału w wojnie - równoznacznego $\mathrm{z}$ uwolnieniem od konieczności ponoszenia $\mathrm{z}$ tego powodu jakichkolwiek konsekwencji karnych - dotyczyła zapewne większości z nich. Uczestnictwa w wojnie wyniszczającej - wojnie, jednym z celów której jest systematyczne naruszanie reguł ius in bello - nie sposób jednak moralnie usprawiedliwić ${ }^{3}$.

\section{INDYWIDUALNA ODPOWIEDZIALNOŚĆ ŻOŁNIERZY ZA UCZESTNICTWO W WOJNIE WYNISZCZAJĄCEJ}

Możliwość przypisania poszczególnym żołnierzom moralnej odpowiedzialności za ich uczestnictwo w wojnie - niezależnie od jej stopnia oraz wszelkich okoliczności mogących wpływać na jej ewentualne ograniczenie - jest podstawowym warunkiem zachowania przez nich - przynajmniej w minimalnym zakresie - statusu podmiotowego względem własnych działań. W ujęciu proponowanym przez Walzera, moment zaangażowania się jednostki (dobrowolnego czy tez wymuszonego przez państwo) w konflikt zbrojny oznacza nieuchronnie przekształcenie się jej w „ludzkie narzędzie” własnego państwa. To dopiero w takiej roli ma ona uzyskiwać atut moralnej równości w odniesieniu do wszystkich innych walczących - przede

23 Szerzej na temat różnicy między „usprawiedliwieniem” a „wytłumaczeniem”, zob. J. Mc-Mahan, Etyka zabijania na wojnie, dz. cyt., 106-110. 
wszystkim tych, którzy walczą po stronie przeciwnej. „Najczęściejpisze Walzer - [żołnierze] wierzą w sprawiedliwość swych wojen, a choć podstawą tej wiary niekoniecznie jest racjonalny namysł, lecz znacznie częściej ślepe godzenie się z oficjalną propagandą, niemniej nie są oni przestępcami; stają naprzeciw siebie jako równi moralnie"24. Moralna równość żołnierzy okazuje się zatem równością jednostek zasadniczo pozbawionych kluczowych atrybutów moralnego sprawstwa: moralne zrównanie $\mathrm{z}$ wszystkimi pozostałymi uczestnikami wojennego dramatu poprzedzać ma („najczęściej”) wyłączenie, czy wręcz amputacja, umiejętności racjonalnej analizy i oceny rozgrywających się zdarzeń. Trudno zgodzić się z Walzerem, by tego rodzaju eliminacja podstawowych prerogatyw jednostkowej podmiotowości następować miała w takiej skali wśród członków jakiejkolwiek wspólnoty politycznej w konfrontacji z sytuacją generującą konieczność systematycznego narażania własnego życia/odbierania życia innym. Wręcz przeciwnie, ze względu na ekstremalność wyzwań związanych $\mathrm{z}$ zaangażowaniem $\mathrm{w}$ działania wojenne można by raczej w większości przypadków spodziewać się mobilizacji przynajmniej

24 M. Walzer, Wojny sprawiedliwe i niesprawiedliwe, dz. cyt., 201. Jeśli nawet uznać za Walzerem, że uległość względem prowojennej propagandy stanowi najczęstszą okoliczność realnego zaangażowania się jednostki w konflikt zbrojny, kwestią kluczową przy ocenie tego rodzaju postawy pozostaje rozpatrzenie treściowej zawartości owej propagandy jako takiej. Rzeczą oczywistą wydaje się konieczność uwzględnienia zasadniczych różnic między propagandowym przesłaniem przeciwstawnych stron konfliktu - np. między zagrzewaniem niemieckich żołnierzy przez przywódców Trzeciej Rzeszy do pełnego poświęcenia podczas ataku na Polskę 1 września 1939 r., a przynaglaniem współobywateli do wzięcia udziału w obronie własnego kraju ze strony polskich czynników rządowych w sierpniu i wrześniu 1939 r. Nie widać żadnego powodu, by różnice te nie przekładały się na całkowicie odmienną wartość moralną samego uczestnictwa w pierwszym etapie drugiej wojny światowej po przeciwległych stronach frontu. Należy również dostrzec możliwość - dotyczącą niekoniecznie marginalnych przypadków - w pełni świadomej, racjonalnie uzasadnionej decyzji o wzięciu czynnego udziału w wojnie obronnej (czyli wojnie sprawiedliwej). Trudno wyobrazić sobie argumentację, zgodnie z którą postawa taka miałaby zostać uznana za moralnie równoważną „ślepemu godzeniu się” z propagandą państwa-agresora. 
części zasobów konstytuujących osobową autonomię poszczególnych jednostek. Zachowanie przez żołnierzy zdolności do dokonywania moralnego osądu zdarzeń zakłada zresztą sam Walzer: odnosi on ją wprawdzie do przypisywanego im - i wielokrotnie potwierdzanego w rzeczywistości - poszanowania dla konwencji wojennych (czyli reguł ius in bello), jednak sam fakt utrzymania odpowiednich kompetencji w tym zakresie świadczy w sposób niezbity o zasadniczej funkcjonalności jednostkowej świadomości moralnej jako takiej. Co więcej, uznawane przez Walzera ugruntowanie przekonań moralnych w sferze podstawowych relacji społecznych wydaje się analogiczne do takiegoż zakotwiczenia poczucia lojalności względem własnego państwa. Próba przeciwstawiania sobie przywiązania do umocowanych wspólnotowo norm etycznych oraz uległości względem rozpowszechnionej „oficjalnej propagandzie” wojennej nie jest zatem w pełni zasadna ${ }^{25}$.

W przypadku udokumentowanego przez historyków systematycznego charakteru łamania konwencji wojennych przez wojska Wehrmachtu we wrześniu 1939 r. rozdzielenie odpowiedzialności za pogwałcenie ius ad bellum od odpowiedzialności za naruszenie ius in bello okazuje się szczególnie problematyczne. Wyłączenie indywidualnych uczestników niemieckiej agresji na Polskę - w jej konkretnym, historycznie potwierdzonym przebiegu - poza zakres normatywnego oddziaływania zakazu państwowej agresji przeciw innemu państwu stawia nieuchronnie pod znakiem zapytania możliwość jednoczesnego stosowania względem ich działań standardowego zestawu unormowań określających zasięg i skalę dopuszczalnej przemocy militarnej (reguł ius in bello). Trudność

25 „Nie zamierzam twierdzić, że nasze osądy mają - lub choćby przyjmują z czasem - jednoznaczną ogólną formę. Ale nie mają też charakteru czegoś indywidualnego i osobistego. Są społecznie uwarunkowane, a czynnikami tego uwarunkowania są zarówno religia, kultura i polityka, jak i prawo. Zadaniem teoretyka moralności jest zbadanie tego uwarunkowania jako całości i zrozumienie jego najgłębszych racji”. M. Walzer, Wojny sprawiedliwe i niesprawiedliwe, dz. cyt., 94. 
zachowania rozdzielności obydwu perspektyw uwidacznia się w sposób wyrazisty przy próbie oceny postępowania niemieckich lotników zrzucających bomby na śpiących mieszkańców Wielunia: zgodnie z kanoniczną wersją teorii Walzera akt ten trzeba by uznać za zasługujące na potępienie złamanie podstawowej konwencji wojennej, a zarazem za moralnie obojętne (jeśli nie zalecane!) wypełnienie rozkazu dowództwa niemieckiej Luftwaffe. Paradoks ten, odnoszący się do wszystkich innych zbrodni popełnionych na obywatelach Polski przez niemiecką armię, nabiera szczególnej wymowy w świetle słynnego przemówienia Hitlera do wyższych oficerów Wehrmachtu z dnia 22 sierpnia 1939 r., określającego podstawowe założenia strategiczne wojny totalnej ${ }^{26}$. Przy artykułowanym przez przywódcę Trzeciej Rzeszy bezpośrednio, całkowicie jednoznacznym ukierunkowaniu działań wojennych na pełne wyniszczenie biologicznej substancji podbijanego narodu, uwolnienie szeregowych żołnierzy od moralnej odpowiedzialności za samo uczestnictwo w tego rodzaju wojnie oznacza również de facto uwolnienie ich od obowiązku przestrzegania jakichkolwiek zasad ograniczających stosowanie przemocy militarnej.

Jest faktem znamiennym, że zaplanowanemu z rozmysłem rozszerzeniu klasycznych celów niemieckiej operacji wojskowej z września

26 „Celem wojny jest nie osiągnięcie jakiejś określonej linii [terytorialnej], lecz fizyczne zniszczenie wroga. Tak więc przygotowałem - jak na razie tylko na wschodzie - moje oddziały spod znaku trupich główek z rozkazem bezlitosnego wysyłania na łono śmierci mężczyzn, kobiet i dzieci polskiego pochodzenia i polskiego języka. Tylko tak wygramy przestrzeń życiową, której tak pragniemy (...). Polska zostanie wyludniona, a następnie zasiedlona Niemcami. Dla was, moi panowie, nadarza się okazja do zdobycia sławy i honoru, jakiej nie było od stuleci. Bądźcie twardzi, bądźcie bezlitośni, działajcie szybciej i brutalniej niż inni. Obywatele Europy Zachodniej muszą struchleć z przerażenia. To jest najbardziej humanitarny sposób prowadzenia wojny. Gdyż to ich odstraszy". Akten zur deutschen Auswartigen Politik 1918-1945. Aus dem Archiv des Deutschen Auswartigen Amtes [ADAP], Baden-Baden 1956, seria D, t. 7, 171-172, przyp. 1; cyt. za. J.A. Młynarczyk, Niemieckie plany wobec ludności Polski i ich realizacja w 1939 r., w: Spojrzenie na Polski Wrzesień 1939, dz. cyt., 98-99. 
1939 r. o nakaz systematycznego łamania podstawowych konwencji wojennych towarzyszyło oficjalne propagowanie przez niemieckie dowództwo powszechnie obowiązującego charakteru tychże konwencji. Zwraca na to uwagę Szymon Danter, przywołując wskazany przez niemieckiego feldmarszałka Erharda Milcha podczas jego zeznań w Procesie Norymberskim dokument zatytułowany 10 przykazań niemieckiego żotnierza o sposobie prowadzenia wojny. Broszura ta, zawierająca krótkie omówienie kluczowych reguł ius in bello - w tym zasady nienaruszalności życia i mienia ludności cywilnej - dołączana była, wedle zeznań Milcha, do książeczki wojskowej każdego niemieckiego żołnierza ${ }^{27}$. Tym samym, elementarne normy etyczne dotyczące działań zbrojnych - radykalnie zanegowane w sferze strategicznych założeń i szczegółowego przebiegu antypolskiej operacji Wehrmachtu - zachowywać miały formalnie status obowiązujących dyrektyw adresowanych do poszczególnych żołnierzy niemieckiej armii. Klasyczne reguły ius in bello, pozostawione w zasadniczo niezmienionym kształcie jako element prowojennej propagandy nazistowskiego państwa, uzyskiwały zatem swoiste „uzupełnienie” w postaci swej dokładnej odwrotności zakodowanej w aberracyjnie rozbudowanej wersji ius ad bellum (za tego rodzaju hybrydę uznać należy hitlerowską definicję wojny wyniszczającej). W konsekwencji, metodyczne zabijanie cywilów przez niemieckie wojsko okazywało się działaniem o podwójnej naturze: zaangażowanie się w nie - nawet przy ostatecznym uznaniu jego podwójnie zbrodniczego charakteru - dawało szansę poszczególnym żołnierzom

2710 Gebote für die Kriegsführung des deutschen Soldaten. Der Prozess gegen die Hauptkriegsverbrecher vor dem Internationalen Militargerichtshof, Nürnberg 1947, t. IX, 100-101, cyt. za: Sz. Danter, dz. cyt., 28-29. Punkt siódmy broszury, w sposób szczególny podkreślany przez Dantera, posiadał następujące brzmienie: „7. Ludność cywilna jest nietykalna. Nie wolno żołnierzowi rabować ani niszczyć samowolnie jej mienia. Należy szanować szczególnie historyczne pomniki i obiekty kultu oraz gmachy służące sztuce, nauce oraz działalności dobroczynnej. Świadczenia ludności w naturze oraz usługi mogą mieć miejsce jedynie na rozkaz przełożonych i za odszkodowaniem". 
na niezaciąganie na siebie moralnej odpowiedzialności za popełniane zbrodnie. Walzerowska koncepcja (wyłącznie) ponadindywidualnego podmiotu naruszeń ius ad bellum w swej surowej wersji wykładnię taką w sposób nieuchronny legitymizuje.

Próba rewizji tej koncepcji celem wyeksponowania możliwych indywidualnych obciążeń związanych $\mathrm{z}$ uczestnictwem $\mathrm{w}$ wojnie niesprawiedliwej uwzględniać musi - zgodnie z postulatem Walzera - rzeczywiste skomplikowanie historycznych konfliktów zbrojnych. Zbrojna napaść hitlerowskich Niemiec na Polskę w 1939 r. wraz z prowadzoną przez polską armię wojną obronną wydają się stanowić wyjątkowo odpowiednie tło dla teoretycznych dywagacji na temat zasadności walzerowskiej tezy o moralnej równości żołnierzy walczących po obydwu stronach frontu wszelkiego rodzaju wojen. Analiza szeregu kluczowych zdarzeń składających się na przebieg polskiej kampanii wrześniowej pozwala dostrzec kontrowersyjne aspekty jednego z głównych założeń firmowanej przez Walzera klasycznej postaci teorii wojny sprawiedliwej. Wypracowanie oraz uzasadnienie stosownej modyfikacji niezwykle konsekwentnego w tej kwestii stanowiska autora Wojen sprawiedliwych i niesprawiedliwych pozostaje ciągle aktualnym wyzwaniem dla współczesnych badaczy etyki wojny.

\section{BIBLIOGRAFIA}

Anscombe E., War and Murder, w: Nuclear Weapons: A Catholic Response, w: Sheed and Ward, red. W. Stein, London - New York 1961, 45-62.

Böhler J., Najazd 1939. Niemcy przeciw Polsce, tłum. z niem. D. Salomon, Wydawnictwo Znak, Kraków 2011.

Böhler J., Wojna z Polskq w 1939 r. w historiografii zachodnioniemieckiej, w: Spojrzenie na Polski Wrzesień 1939, red. T. Kondracki, Wydawnictwo Neriton, Warszawa 2011, 23-34.

Böhler J., Zbrodnie Wehrmachtu w Polsce. Wrzesieñ 1939. Wojna totalna, Wydawnictwo Znak, Kraków 2009. 
Cebula A., Occasional Inevitability of War Crimes or Ethically Unjustified Hegemony of (Some of) the Rights of Civilians? Some Remarks on the Duplex Nature of Extra-Moral Absolutism, Ethical Perspectives 24(2017)1, 107-122.

Danter Sz., 55 dni Wehrmachtu w Polsce. Zbrodnie na polskiej ludności cywilnej w okresie 1. XI-25. X. 1939, Wydawnictwo Ministerstwa Obrony Narodowej, Warszawa 1967.

Davies N., We must not forget the real causes of the war, The Independent 28.08.2009, http://www.independent.co.uk/voices/commentators/we-must-not-forget-thereal-causes-of-the-war-1778973.html.

McMahan J., Etyka zabijania na wojnie, w: Etyka wojny, red. T. Kuniński, T. Żuradzki, Wydawnictwo Naukowe PWN, Warszawa 2009, 101-143.

McMahan J., Killing in War: A Reply to Walzer, Philosophia 34(2006), 47-51.

Młynarczyk J.A., Niemieckie plany wobec ludności Polski i ich realizacja w 1939 r., w: Spojrzenie na Polski Wrzesień 1939, red. T. Kondracki, Wydawnictwo Neriton, Warszawa 2011, 95-139.

Rigstad M., Putting the War Back in Just War Theory. A Critique of Examples, Ethical Perspectives 24(2017)1, 123-144.

Snyder T., Skrwawione ziemie. Europa między Hitlerem a Stalinem, tłum. z ang. B. Pietrzyk, Świat Książki, Warszawa 2015.

Statman D., Supreme emergencies revisited, Ethics 117(2006)10, 58-79.

Toner Ch., Just war and the Supreme Emergency Exemption, The Philosophical Quarterly 55(2005)221, 545-561.

Vitoria F. de, De iure belli, w: Francisco de Vitoria: Political Writings, red. J. Lawrance, A. Pagden, tłum. na ang. J. Lawrance, Cambridge University Press, Cambridge 1991, 293-328.

Walzer M., Just and Unjust Wars, Basic Books, New York 2015.

Walzer M., Response to McMahan's Paper, Philosophia 34(2006), 43-45.

Walzer M., Wojny sprawiedliwe i niesprawiedliwe, tłum. z ang. M. Szczubiałka, Wydawnictwo Naukowe PWN, Warszawa 2010.

Włodkowic P., Saevientibus, w: Dzieła wybrane Pawta Wtodkowica, red. L. Ehrlich, Vol. I, Instytut Wydawniczy PAX, Warszawa 1968, 2-112.

\section{YEARS AFTER MICHAEL WALZER'S JUST AND UNJUST WARS. SOME REMARKS ON THE PRINCIPLE OF THE MORAL EQUALITY OF SOLDIERS}

Abstract. This article contains a brief analysis of a key assumption of Michael Walzer's version of just war theory, presented in his main work devoted to the ethics of war. In compliance with the requirement of the author of Just and unjust wars, the controversial 
nature of the principle of the moral equality of soldiers is exposed through a close analysis of the course of events marking the beginning of World War II - one of the main issues dealt with in Walzer's book. The exclusion of individual responsibility for taking part in a military operation that finds no moral justification seems to entail a number of consequences that put a heavy burden on Walzer's overall model of military ethics. In order to maintain the required level of coherence in just war theory one may need to modify Walzer's principle of the moral equality of soldiers - at least in relation to the participants of the so-called devastating war.

Keywords: ethics of war, just war theory, moral equality of soldiers, war propaganda, individual moral responsibility

\author{
Adam Cebula \\ a.cebula@uksw.edu.pl \\ Uniwersytet Kardynała Stefana Wyszyńskiego w Warszawie, Instytut Filozofii \\ Wóycickiego 1/3, 01-938 Warszawa
}

DOI: 10.21697/spch.2017.53.3.09 